\title{
Anti-Parasite Activity of Novel 3,5-Diiodophenethyl-benzamides
}

\author{
Manuel Pastrana Restrepo, ${ }^{\circledR a}$ Verónica Surmay Surmay, ${ }^{a}$ Elkin Galeano Jaramillo $*, a$ \\ and Sara Robledo Restrepo ${ }^{b}$
}

\author{
${ }^{a}$ Productos Naturales Marinos, Departamento de Farmacia, \\ Facultad de Ciencias Farmacéuticas y Alimentarias, Universidad de Antioquia (UdeA), \\ Calle 70 No. 52-21, Laboratorio 2-131, 050010 Medellín, Colombia \\ ${ }^{b}$ Programa de Estudio y Control de Enfermedades Tropicales (PECET), Facultad de Medicina, \\ Universidad de Antioquia (UdeA), Calle 62 No. 52-59, Laboratorio 632, \\ 050010 Medellín, Colombia
}

\begin{abstract}
Novel iodotyramides with para-substituted benzoic acids were synthesized via electrophilic aromatic substitutions and amide coupling via $N, N^{\prime}$-diisopropylcarbodiimide (DIC) in dimethylformamide (DMF). All derivatives were in vitro screened against U-937 macrophages and Plasmodium falciparum, Leishmania panamensis and Trypanosoma cruzi protozoan parasites. The hemolytic activity was evaluated on human red blood cells (RBC). Compounds $N$-(4-hydroxy-3,5-diiodophenethyl)-4-methylbenzamide and $N$-(3,5-diiodo4-methoxyphenethyl)-4-methoxybenzamide were the most active against L. panamensis with an effective concentration $50\left(\mathrm{EC}_{50}\right)$ of 17.9 and $17.5 \mu \mathrm{g} \mathrm{mL} \mathrm{m}^{-1}$, respectively; while compounds $N$-(3,5-diiodo-4-methoxyphenethyl)-4-methylbenzamide and $N$-(3,5-diiodo-4-methoxyphenethyl)4-methoxybenzamide were the most active for T. cruzi with $\mathrm{EC}_{50}$ values of 23.75 and $6.19 \mu \mathrm{g} \mathrm{mL}^{-1}$, respectively. In contrast, all derivatives showed high activity against $P$. falciparum with $\mathrm{EC}_{50}<25 \mu \mathrm{g} \mathrm{mL} \mathrm{m}^{-1}$, except compound $N$-(4-hydroxy-3,5-diiodophenethyl)-benzamide. No compound was hemolytic over RBC. This report represents the importance of novel iodotyramides as anti-parasites agents.
\end{abstract}

Keywords: anti-protozoan activity, cytotoxicity, L. panamensis, P. falciparum, T. cruzi, iodotyramides

\section{Introduction}

Marine organisms represent a large source of primary and secondary bioactive metabolites. Halogenated alkaloids, especially those with iodine atoms, are a type of secondary metabolites with diverse biological activities. While iodinated halometabolites are hard to find in nature, chloro and bromo derivatives alkaloids are more common. ${ }^{1}$ Nevertheless, ten iodotyramine derivatives (3,5-diiodotyramines and tyrosine derivatives) with antitumoral activity were recently isolated from the aqueous extract of ascidian Didemnиm rubeum. ${ }^{2}$ Moreover, iodine derivative alkaloid 3,5-diiodo-4-methoxyphenetylamine and their respective urea analogs were isolated from the tunicates Lissoclinum patella and Didemnum ternatanum. Both derivatives were active against $C$. albicans strains and mouse lymphocytic leukemia L1210 cell line at concentrations of half maximal

*e-mail: elkin.galeano@udea.edu.co inhibitory concentration $\left(\mathrm{IC}_{50}\right) 20 \mu \mathrm{g} \mathrm{mL} \mathrm{L}^{-1} .^{3}$ Other active diiodotyramines isolated from marine organisms are turbotoxins A and B both isolated from gastropod Turbo marmorata. These diiodotyramines exhibited an acute toxicity against ddY mice, with an dosage required to kill $99 \%$ of the test population $\left(\mathrm{LD}_{99}\right)$ of 1.0 and $4.0 \mathrm{mg} \mathrm{kg}^{-1}$, respectively. ${ }^{4}$ However, their synthetic analogs were 100fold less toxic when the quaternary ammonium group was changed by a tertiary ammonium group. ${ }^{5}$ Due to iodinated alkaloid metabolites, usually isolated as tyrosine and tyramine derivatives, diiodotyramides and diiodotyrosines show broad biological activities, but are not very common in nature, therefore, chemical synthesis of these compounds emerge as an opportunity to potentiate their biological activity through structural changes and develop new active agents that may overcome the problem of parasite resistance against current drugs. For this reason, the potential of synthetic compounds based on diiodotyramides aromatic esters, derivatives of marine natural products, was evaluated 
in this study for cytotoxicity, but also for anti-protozoan and hemolysis activities.

\section{Results and Discussion}

\section{Chemistry}

The aromatic iodo-tyramides syntheses were made in two stages (Scheme 1). The first is the synthesis of compounds $\mathbf{C}$ and $\mathbf{D}$, and later coupling with different aromatic acids to afford the respective amides.

The protection of the amino group in the tyramine was done in basic media with $\mathrm{Boc}_{2} \mathrm{C},{ }^{6}$ and the diiodination of the aromatic ring with $\mathrm{N}$-iodosuccinimide (NIS), ${ }^{7}$ getting a di-halogenated compound in positions 3 and 5, obtaining compound $\mathbf{A}$ with a $70 \%$ yield for two steps. ${ }^{1} \mathrm{H}$ nuclear magnetic resonance (NMR) analysis of compound $\mathbf{A}$ shows a singlet at $7.50 \mathrm{ppm}$ for two protons, which corresponds to hydrogen at 2 , which confirm the diiodination at the ortho position of the phenyl ring. The singlet at $1.44 \mathrm{ppm}$ for nine protons corresponds to $t$-butyl group for the carbamate moiety. Compound $\mathbf{B}$ was produced by the reaction of $\mathbf{A}$ with methyl iodide in basic media, ${ }^{8}$ with $80 \%$ yield. ${ }^{1} \mathrm{H}$ NMR spectra of compound $\mathbf{B}$ shows a singlet at $3.84 \mathrm{ppm}$ for three protons, corresponding to $O$-methyl group in the aromatic ring.

Acid hydrolysis of compounds $\mathbf{A}$ and $\mathbf{B}^{9}$ produce the primary amines in compounds $\mathbf{C}$ and $\mathbf{D}$. The loss of the signal at $1.44 \mathrm{ppm}$ in both compounds shows the hydrolysis of the carbamate moiety.

The amide syntheses were done by the coupling of $\mathbf{C}$ and $\mathbf{D}$ with different aromatic acids using $N, N$ '-diisopropyl- carbodiimide (DIC) in dimethylformamide (DMF) catalyzed with 4-dimethylaminopyridine (DMAP), ${ }^{10}$ in yields ranging $45-50 \% .{ }^{1} \mathrm{H}$ NMR analysis of the amides shows the respective singlet for two protons in the downfield area corresponding to hydrogens at ortho position in the iodo-tyramine moiety. Besides, the signals corresponding to the aromatic protons in the aromatic acids scaffold appear in the 6-8 ppm region. $p$-Substituted aromatic acids show these signals as two doublets confirming the symmetry of the aromatic ring. The presence of methyl and $O$-methyl groups in the aromatic rings was confirmed by the singlets at 2.34 and $3.70 \mathrm{ppm}$. The ${ }^{1} \mathrm{H}-{ }^{1} \mathrm{H}$ correlation spectroscopy (COSY) analysis shows the respective couplings of protons in the aromatic acid and two methylene group in the iodotyramine chain. The molecular formula of the respective amides was confirmed by high-resolution mass spectra (HRMS) analysis. In this way it was possible to determine unambiguously the chemical structure of the new derivatives synthesized.

\section{Biological activities}

The effect of the eight synthesized amides on cell growth and viability on human U-937 macrophages was assessed. In addition, the anti-parasite activity on L. panamensis and T. cruzi intracellular amastigotes and total sexual forms of $P$. falciparum was tested, according to the ability of compounds to reduce the amount of parasite in culture. The hemolytic assay was done on human red blood cells (RBC) obtained from a blood bank. Results are summarized in Table 1.<smiles>CC(C)CC(=O)NCCc1cc(I)c(O)c(I)c1</smiles>
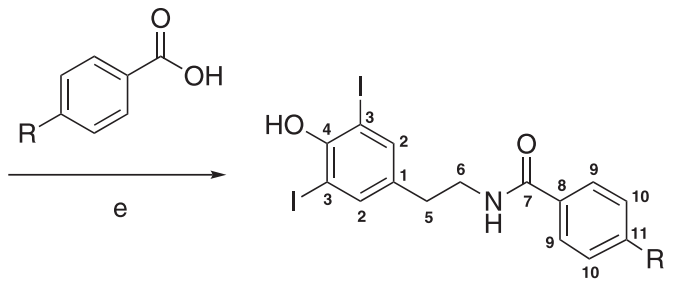

Comp 1. $\mathrm{R}=\mathrm{H}$ Comp 2. $\mathrm{R}=\mathrm{Me}$ Comp 3. $\mathrm{R}=\mathrm{OMe}$ Comp 4. $\mathrm{R}=\mathrm{NO}_{2}$
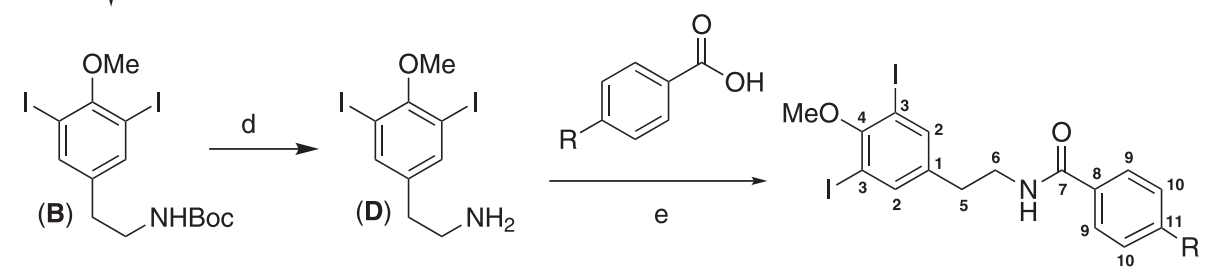

Comp 5. $\mathrm{R}=\mathrm{H}$

Comp 6. $\mathrm{R}=\mathrm{Me}$

Comp 7. $\mathrm{R}=\mathrm{OMe}$

Comp 8. $\mathrm{R}=\mathrm{NO}_{2}$ 
Table 1. Biological activities of diiodotyramides derivatives

\begin{tabular}{|c|c|c|c|c|c|c|c|c|}
\hline \multirow{2}{*}{ Compound } & \multirow{2}{*}{$\frac{\mathrm{U}-937}{\mathrm{LC}_{50} /\left(\mu \mathrm{g} \mathrm{mL} \mathrm{L}^{-1}\right)}$} & \multicolumn{2}{|c|}{ L. panamensis } & \multicolumn{2}{|c|}{ T. cruzi $i$} & \multicolumn{2}{|c|}{ P. falciparum } & \multirow{2}{*}{$\begin{array}{c}\mathrm{RBC} \\
\mathrm{LC}_{50} /\left(\mu \mathrm{g} \mathrm{mL}^{-1}\right)\end{array}$} \\
\hline & & $\mathrm{EC}_{50} /\left(\mu \mathrm{g} \mathrm{mL}^{-1}\right)$ & SI & $\mathrm{EC}_{50} /\left(\mu \mathrm{g} \mathrm{mL}^{-1}\right)$ & SI & $\mathrm{EC}_{50} /\left(\mu \mathrm{g} \mathrm{mL}^{-1}\right)$ & SI & \\
\hline 1 & $323.2 \pm 51.68$ & $46.33 \pm 17.5$ & 6.97 & $62.09 \pm 10.36$ & 5.2 & $97.69 \pm 10.12$ & 3.31 & $>200$ \\
\hline 2 & $81.4 \pm 15.4$ & $17.9 \pm 8.77$ & 4.55 & $28.88 \pm 1.74$ & 2.81 & $27.08 \pm 1.96$ & 3.01 & $>200$ \\
\hline 3 & $75.22 \pm 15.4$ & $51.54 \pm 69.8$ & 1.46 & $67.29 \pm 6.77$ & 1.11 & $20.45 \pm 1.14$ & $<9.77$ & $>200$ \\
\hline 4 & $38.67 \pm 7.12$ & $>50$ & $<0.77$ & $111.37 \pm 246.97$ & 0.03 & $21.15 \pm 1.81$ & $>9.45$ & $>200$ \\
\hline 5 & $32.73 \pm 5.17$ & $33.77 \pm 22.53$ & 0.97 & $30.34 \pm 2.46$ & 1.08 & $20.41 \pm 1.51$ & $>9.79$ & $>200$ \\
\hline 6 & $24.12 \pm 3.9$ & $38.21 \pm 14.87$ & 0.63 & $23.75 \pm 2.85$ & 1.02 & $18.49 \pm 0.89$ & $>10.81$ & $>200$ \\
\hline 7 & $12.86 \pm 0.46$ & $17.5 \pm 17.77$ & 0.73 & $6.19 \pm 0.18$ & 2.08 & $22.6 \pm 1.72$ & $>8.84$ & $>200$ \\
\hline 8 & $88.49 \pm 21.5$ & $37.43 \pm 32.83$ & 2.36 & $26 \pm 2.28$ & 3.4 & $19.07 \pm 1.88$ & 10.48 & $>200$ \\
\hline Doxorubicin & $1.37 \pm 0.6$ & NA & NA & NA & NA & NA & NA & NA \\
\hline Amphotericin B & $36.6 \pm 8$ & $0.09 \pm 0.01$ & 406.66 & NA & NA & NA & NA & NA \\
\hline Benznidazole & $>200$ & NA & NA & $14.78 \pm 0.28$ & $>13.53$ & NA & NA & NA \\
\hline Chloroquine & $155.2 \pm 5.2$ & NA & NA & NA & NA & $3.36 \pm 0.4$ & 46.19 & NA \\
\hline
\end{tabular}

RBC: red blood cells; $\mathrm{EC}_{50}$ : effective concentration $50 ; \mathrm{LC}_{50}$ : lethal concentration 50; SI: selectivity index $=\mathrm{LC}_{50} / \mathrm{EC}_{50}$; NA: no apply.

The anti-parasite activities were measured by determining the effective concentration $50\left(\mathrm{EC}_{50}\right)$. The anti-leishmanial assay showed that compounds $\mathbf{2}$ and $\mathbf{7}$ were the most active with $\mathrm{EC}_{50}$ of 17.9 and $17.5 \mu \mathrm{g} \mathrm{mL}^{-1}$, respectively. Compounds $\mathbf{1}, \mathbf{3}, \mathbf{5}, \mathbf{6}$ and $\mathbf{8}$ had moderate activity with $\mathrm{EC}_{50}$ values between 25 to $50 \mu \mathrm{g} \mathrm{mL}^{-1}$. The compound with the highest selectivity index (SI) for L. panamnesis was compound $\mathbf{1}$ with a value of $6.97 \mu \mathrm{g} \mathrm{mL}^{-1}$. It is the safest of the iodotyramides derivatives. Compound $\mathbf{1}$ was more than 8 -fold less cytotoxic than amphotericin B. Anti-trypanosomal assays showed that compounds $\mathbf{6}$ and $\mathbf{7}$ were the most active with $\mathrm{EC}_{50}$ of 23.75 and $6.19 \mu \mathrm{g} \mathrm{mL} \mathrm{m}^{-1}$, respectively. Moreover, compound 7 was more active than benznidazole. In turn, compounds $\mathbf{2}, \mathbf{5}$ and $\mathbf{8}$ were moderately active with values ranging from 25 to $50 \mu \mathrm{g} \mathrm{mL} \mathrm{m}^{-1}$. Compound $\mathbf{1}$ was the most selective against $T$. cruzi with an SI of 5.2.

Finally, antiplasmodial activity showed that all derivatives had a high activity with $\mathrm{EC}_{50}$ values $<25 \mu \mathrm{g} \mathrm{mL}^{-1}$, except compound $\mathbf{1}$. No compound was more active than chloroquine. Compound $\mathbf{8}$ had the highest SI with a value of 10.48. Compounds 4, 5, 6 and $\mathbf{7}$ were also selective with $\mathrm{SI}$ values $>8$. The $p$-O-Me compounds were most active than their more polar analogs against $L$. panamnesis and T. cruzi. The core A, 3,5-diiodo- $p$-methoxybenzyl, is correlated with a higher antiparasitic activity against the three parasites tested. Those derivatives showed the best selectivity index against $P$. falciparum. No compound was hemolytic on human RBC.

\section{Conclusions}

In this work it is reported the complete synthesis of $\mathrm{N}$-(3,5-diiodo-4-methoxyphenethyl)-benzamide, an iodotyramide isolated for the first time from ascidian
Didemnun rubeum and seven correlated new tyramides with different substitution in para-position of the aromatic acid moiety. Antiparasitic activity against T. cruzi, L. panamensis and P. falciparum and also cytotoxicity and hemolysis assays were reported. All compounds had $\mathrm{LC}_{50}<100 \mu \mathrm{g} \mathrm{mL}$, except compound $\mathbf{1}$, making them potentially cytotoxic for U-937 macrophages. Compounds $\mathbf{2 - 8}$ had high activity against $P$. falciparum, where compound $\mathbf{6}$ was the most promissory compound. Anti-trypanosomal assays showed that compounds $\mathbf{6}$ and $\mathbf{7}$ had the higher activity, where $\mathbf{7}$ was the most active against T. cruzi. In turn, anti-leishmanial assays showed that compounds $\mathbf{2}$ and $\mathbf{7}$ were the most active. No compound produced hemolysis of RBC. Based on these in vitro biological activities, further in vivo studies are necessary to validate anti-parasite activity observed of compounds $\mathbf{2 ,} 6$ and 7.

\section{Experimental}

\section{General remarks}

All laboratory reagents were analytical grade (SigmaAldrich ${ }^{\circledR}$ ). Chromatography column and HPLC solvents were liquid chromatography grade $\left(\mathrm{Merck}^{\circledR}\right)$. Compound purifications were made by column chromatography using Merck $^{\circledR}$ silica gel 60 and mixtures of hexane and ethyl acetate. Purifications of biologically tested compounds were made by HPLC Agilent 1200 with DAD detector (254, 280 and $366 \mathrm{~nm}$ ) and Eclipse XDB-C18 column using a mixture of $\mathrm{MeOH}$ and $\mathrm{H}_{2} \mathrm{O} 0.1 \%$ formic acid as the mobile phase. ${ }^{1} \mathrm{H}$ and ${ }^{13} \mathrm{C}$ NMR were recorded on Bruker Ascend III HD (600 and $125 \mathrm{MHz}$ ) with $5 \mathrm{~mm}$ cryoprobe TCI, using $\mathrm{CDCl}_{3}$ and dimethyl sulfoxide (DMSO- $d_{6}$ ) as deuterated solvents. Signals were assigned using two-dimensional heteronuclear 
correlations (COSY (correlation spectroscopy) and HSQC (heteronuclear single quantum correlation)). HRMS were recorded using electrospray ionization (ESI-MS) in a UPLC-Q-Tof, reference Xevo-XS-Qtof, Waters. The drying and cone gas was nitrogen set to flow rates of 300 and $30 \mathrm{~L} \mathrm{~h}^{-1}$, respectively. Methanol samples solutions $\left(1 \times 10^{-5} \mathrm{~mol} \mathrm{~L}^{-1}\right)$ were directly introduced into the ESI spectrometer at a flow rate of $10 \mu \mathrm{L} \mathrm{min}^{-1}$. A capillary voltage $3.5 \mathrm{kV}$ was used in the positive scan mode, and the cone voltage set to $\mathrm{Uc}=10 \mathrm{~V}$.

\section{Chemistry}

Synthetic procedure for tert-butyl-(4-hydroxy-3,5-diiodophenethyl)-carbamate (compound $\mathbf{A}$ )

Tyramine (1500 mg, $10.9 \mathrm{mmol}), \mathrm{Boc}_{2} \mathrm{O}(2756 \mu \mathrm{L}$, $12 \mathrm{mmol})$, triethylamine (TEA) $(600 \mu \mathrm{L})$ and $\mathrm{MeOH}$ $(20 \mathrm{~mL})$ were placed into a round bottom flask equipped with a magnetic stirring bar. The mixture was stirred at room temperature for $24 \mathrm{~h}$. The crude reaction mixture was evaporated under reduced pressure and the residue was purified by column chromatography over silica gel eluting with hexane-ethyl acetate (4:1 to 1:1) affording a pale yellow oil, quantitative conversion. The previous product was dissolved in $\mathrm{MeOH}(20 \mathrm{~mL})$ and NIS $(5400 \mathrm{mg}$, $24 \mathrm{mmol}$ ) and it was placed into a round bottom flask equipped with a magnetic stirring bar. The mixture was stirred at room temperature for $24 \mathrm{~h}$. The crude reaction mixture was evaporated under reduced pressure and the residue was purified by column chromatography over silica gel eluting with hexane-ethyl acetate (4:1 to 1:1) affording a pale yellow oil. Yield 70\%, $3820 \mathrm{mg} ;{ }^{1} \mathrm{H}$ NMR $(600 \mathrm{MHz}$, $\left.\mathrm{CDCl}_{3}\right) \delta 7.50(\mathrm{~s}, 2 \mathrm{H}, \mathrm{H}-2), 5.71(\mathrm{~s}, 1 \mathrm{H}, \mathrm{NH}), 3.28(\mathrm{q}, 2 \mathrm{H}$, H-6), 2.66 (t, 2H, H-5), 1.44 (s, 9H, C( $\left.\left(\mathrm{CH}_{3}\right)_{3}\right)$.

Synthetic procedure for tert-butyl-(3,5-diiodo-4-methoxyphenethyl)-carbamate (compound $\mathbf{B}$ )

Compound A (1900 mg, $3.8 \mathrm{mmol}), \mathrm{K}_{2} \mathrm{CO}_{3}(552 \mathrm{mg}$, $4 \mathrm{mmol})$, MeI ( $373 \mu \mathrm{L}, 6 \mathrm{mmol})$ and acetone $(15 \mathrm{~mL})$ were placed into a round bottom flask equipped with a magnetic stirring bar. The mixture was stirred at room temperature for $24 \mathrm{~h}$. The crude reaction mixture was evaporated under reduced pressure and the residue was purified by column chromatography over silica gel eluting with hexane-ethyl acetate (4:1 to 1:1) affording a pale yellow oil. Yield $80 \%$, $1500 \mathrm{mg} ;{ }^{1} \mathrm{H}$ NMR (600 MHz, $\left.\mathrm{CDCl}_{3}\right) \delta 7.59$ (s, 2H, H-2), 3.84 (s, 3H, $\left.\mathrm{OCH}_{3}\right), 3.31$ (q, 2H, H-6), 2.68 (t, 2H, H-5), $1.45\left(\mathrm{~s}, 9 \mathrm{H}, \mathrm{C}\left(\mathrm{CH}_{3}\right)_{3}\right)$.

Synthetic procedure for 3,5-diiodo-tyramine (compound C) Compound A (1000 mg), HCl 37\% (1 mL) and EtOAc
( $3 \mathrm{~mL}$ ) were placed into a round bottom flask equipped with a magnetic stirring bar. The mixture was stirred at room temperature for $3 \mathrm{~h}$. The crude reaction mixture was evaporated under reduced pressure and the residue was neutralized with $10 \% \mathrm{NaHCO}_{3}$ and filtered affording white solids in a quantitative cleavage. ${ }^{1} \mathrm{H}$ NMR $(600 \mathrm{MHz}$, DMSO- $d_{6}$ ) $\delta 7.64$ (s, 2H, H-2), 2.97 (t, 2H, H-6), 2.76 (t, 2H, H-5).

Synthetic procedure for O-methyl-3,5-diiodo-tyramine (compound D)

Compound $\mathbf{B}$ (1000 mg), $\mathrm{HCl} 37 \%$ (1 mL) and EtOAc $(3 \mathrm{~mL})$ were placed into a round bottom flask equipped with a magnetic stirring bar. The mixture was stirred at room temperature for $3 \mathrm{~h}$. The crude reaction mixture was evaporated under reduced pressure and the residue was neutralized with $10 \% \mathrm{NaHCO}_{3}$ and filtered affording white solids in a quantitative cleavage. ${ }^{1} \mathrm{H} \mathrm{NMR}(600 \mathrm{MHz}$, DMSO- $d_{6}$ ) $\delta 7.75$ (s, 2H, H-2), $3.72\left(\mathrm{~s}, 3 \mathrm{H}, \mathrm{OCH}_{3}\right), 3.01$ (q, 2H, H-6), 2.80 (t, 2H, H-5).

General procedure for the synthesis of aromatic tyramides (1-8)

Compound $\mathbf{C}$ or $\mathbf{D}(0.15 \mathrm{mmol})$, DIC $(1.28 \mathrm{mmol}$, $200 \mu \mathrm{L}$ ), DMAP $(0.5 \mathrm{mmol}, 61 \mathrm{mg}$ ), aromatic acid (benzoic acid, 4-methyl benzoic acid, 4-methoxy benzoic acid and 4-nitrobenzoic acid) $(0.5 \mathrm{mmol})$ and DMF $(10 \mathrm{~mL})$ were placed into a round bottom flask equipped with a magnetic stirring bar. The mixture was stirred at room temperature for $36 \mathrm{~h}$. The crude reaction mixture was evaporated under reduced pressure and the residue was purified by column chromatography over silica gel eluting with hexane-ethyl acetate ( $4: 1$ to $1: 1)$ to obtain the aromatic iodotyramides.

$\mathrm{N}$-(4-Hydroxy-3,5-diiodophenethyl)-benzamide (1)

Yield 48\% (51.1 mg, $0.10 \mathrm{mmol}$ ); white solid; ${ }^{1} \mathrm{H}$ NMR $\left(600 \mathrm{MHz}, \mathrm{DMSO}-d_{6}\right) \delta 9.33(\mathrm{~s}, 1 \mathrm{H}, \mathrm{OH}), 8.48(\mathrm{t}, J 4.7 \mathrm{~Hz}$, $1 \mathrm{H}, \mathrm{NH}), 7.78$ (d, J 7.6 Hz, 2H, H-9), 7.61 (s, 2H, H-2), 7.51 (t, J 7.2 Hz, 1H, H-11), 7.45 (t, J 7.3 Hz, 2H, H-10), 3.41 (q, $J 6.1 \mathrm{~Hz}, 1 \mathrm{H}, \mathrm{H}-6), 2.71(\mathrm{t}, J 6.7 \mathrm{~Hz}, 1 \mathrm{H}, \mathrm{H}-5) ;{ }^{13} \mathrm{C}$ NMR $\left(151 \mathrm{MHz}, \mathrm{DMSO}-d_{6}\right) \delta 166.33$ (C-7), 153.58 (C-4), 139.29 (C-2), 135.85 (C-1), 134.66 (C-8), 131.05 (C-11), 128.24 (C-10), 127.10 (C-9), 87.12 (C-3), 40.60 (C-6), 32.76 (C-5); ESI-Qtof-HRMS $m / z$, calcd. for $\mathrm{C}_{15} \mathrm{H}_{14} \mathrm{I}_{2} \mathrm{NO}_{2}$ $[\mathrm{M}+\mathrm{H}]^{+}:$493.9114, found: 493.9159 .

$\mathrm{N}$-(4-Hydroxy-3,5-diiodophenethyl)-4-methylbenzamide (2)

Yield 45\% (49.2 mg, $0.09 \mathrm{mmol}$ ); white solid; ${ }^{1} \mathrm{H}$ NMR $\left(600 \mathrm{MHz}, \mathrm{DMSO}-d_{6}\right) \delta 9.33(\mathrm{~s}, 1 \mathrm{H}, \mathrm{OH}), 8.40(\mathrm{t}, J 4.7 \mathrm{~Hz}$, 1H, NH), 7.69 (d, J 7.6 Hz, 2H, H-9), 7.60 (s, 2H, H-2), 
7.25 (d, J 7.5 Hz, 2H, H-10), 3.39 (q, J $6.0 \mathrm{~Hz}, 2 \mathrm{H}, \mathrm{H}-6$ ), $2.70(\mathrm{t}, J 6.7 \mathrm{~Hz}, 2 \mathrm{H}, \mathrm{H}-5), 2.34\left(\mathrm{~s}, 3 \mathrm{H}, \mathrm{CH}_{3}\right) ;{ }^{13} \mathrm{C} \mathrm{NMR}$ $\left(151 \mathrm{MHz}, \mathrm{DMSO}-d_{6}\right) \delta 166.18(\mathrm{C}-7), 153.57(\mathrm{C}-4)$, 140.86 (C-11), 139.28 (C-2), 135.89 (C-1), 131.85 (C-8), 128.75 (C-10), 127.12 (C-9), 87.11 (C-3), 40.58 (C-6), 32.81 (C-5), $20.95\left(\mathrm{CH}_{3}\right)$; ESI-Qtof-HRMS $\mathrm{m} / 2$, calcd. for $\mathrm{C}_{16} \mathrm{H}_{16} \mathrm{I}_{2} \mathrm{NO}_{2}[\mathrm{M}+\mathrm{H}]^{+}:$507.9270, found: 507.9267.

$N$-(4-Hydroxy-3,5-diiodophenethyl)-4-methoxybenzamide (3)

Yield 46\% (51.9 mg, $0.10 \mathrm{mmol}$ ); white solid; ${ }^{1} \mathrm{H}$ NMR $\left(600 \mathrm{MHz}, \mathrm{DMSO}-d_{6}\right) \delta 9.32(\mathrm{~s}, 1 \mathrm{H}, \mathrm{OH}), 8.34(\mathrm{t}, J 4.6 \mathrm{~Hz}$, 1H, NH), 7.77 (d, J 7.9 Hz, 2H, H-9), 7.59 (s, 2H, H-2), 6.98 (d, J 7.9 Hz, 2H, H-10), 3.80 (s, 3H, $\mathrm{OCH}_{3}$ ), 3.38 (q, $J 6.3 \mathrm{~Hz}, 2 \mathrm{H}, \mathrm{H}-6), 2.69$ (t, J $6.8 \mathrm{~Hz}, 2 \mathrm{H}, \mathrm{H}-5) ;{ }^{13} \mathrm{C} \mathrm{NMR}$ $\left(151 \mathrm{MHz}, \mathrm{DMSO}-d_{6}\right) \delta 166.75$ (C-7), 161.43 (C-11), 153.56 (C-4), 139.25 (C-2), 135.93 (C-9), 128.91 (C-9), 113.43 (C-10), 87.12 (C-2), $55.32\left(\mathrm{OCH}_{3}\right), 40.58$ (C-6), 32.86 (C-5); ESI-Qtof-HRMS m/z, calcd. for $\mathrm{C}_{16} \mathrm{H}_{16} \mathrm{I}_{2} \mathrm{NO}_{3}$ $[\mathrm{M}+\mathrm{H}]^{+}:$523.9220, found: 523.9233.

$\mathrm{N}$-(4-Hydroxy-3,5-diiodophenethyl)-4-nitrobenzamide (4)

Yield 50\% (58.0 mg, $0.10 \mathrm{mmol}$ ); white solid; ${ }^{1} \mathrm{H}$ NMR $\left(600 \mathrm{MHz}, \mathrm{DMSO}-d_{6}\right) \delta 9.34(\mathrm{~s}, 1 \mathrm{H}, \mathrm{OH}), 8.83(\mathrm{t}, J 5.0 \mathrm{~Hz}$, $1 \mathrm{H}, \mathrm{NH}), 8.31$ (d, J 7.8 Hz, 2H, H-10), 8.01 (d, J 7.8 Hz, 2H, H-9), 7.61 (s, 2H, H-2), 3.44 (q, J 6.1 Hz, 2H, H-6), $2.72(\mathrm{t}, J 6.8 \mathrm{~Hz}, 2 \mathrm{H}, \mathrm{H}-5) ;{ }^{13} \mathrm{C}$ NMR (151 MHz, DMSO- $\left.d_{6}\right)$ $\delta 164.64(\mathrm{C}-7), 153.65$ (C-11), 148.95 (C-4), 140.22 (C-8), 139.28 (C-2), 135.61 (C-1), 128.62 (C-9), 123.52 (C-10), 87.14 (C-3), 40.77 (C-6), 32.57 (C-5); ESI-Qtof-HRMS $m / z$, calcd. for $\mathrm{C}_{15} \mathrm{H}_{13} \mathrm{I}_{2} \mathrm{~N}_{2} \mathrm{O}_{4}[\mathrm{M}+\mathrm{H}]^{+}: 538.8965$, found: 538.8981 .

\section{$\mathrm{N}$-(3,5-Diiodo-4-methoxyphenethyl)-benzamide (5)}

Yield 50\% (53 mg, $0.10 \mathrm{mmol}$ ); white solid; ${ }^{1} \mathrm{H}$ NMR $\left(600 \mathrm{MHz}, \mathrm{DMSO}-d_{6}\right) \delta 8.51(\mathrm{t}, J 5.4 \mathrm{~Hz}, 1 \mathrm{H}, \mathrm{NH}), 7.78$ (d, J 7.7 Hz, 2H, H-9), 7.70 (s, 2H, H-2), 7.51 (t, J 7.3 Hz, $1 \mathrm{H}, \mathrm{H}-11), 7.45$ (t, J $7.6 \mathrm{~Hz}, 2 \mathrm{H}, \mathrm{H}-10), 3.71$ (s, 3H, $\mathrm{OCH}_{3}$ ), 3.43 (q, J $\left.6.6 \mathrm{~Hz}, 2 \mathrm{H}, \mathrm{H}-6\right), 2.76$ (t, J $6.9 \mathrm{~Hz}, 2 \mathrm{H}$, $\mathrm{H}-5) ;{ }^{13} \mathrm{C}$ NMR (151 MHz, DMSO- $\left.d_{6}\right) \delta 166.40$ (C-7), 156.69 (C-4), 140.08 (C-1), 139.82 (C-2), 131.11 (C-11), 128.27 (C-10), 127.11 (C-9), 91.15 (C-3), $60.22\left(\mathrm{OCH}_{3}\right)$, 40.39 (C-6), 32.93 (C-5); ESI-Qtof-HRMS m/z, calcd. for $\mathrm{C}_{16} \mathrm{H}_{16} \mathrm{I}_{2} \mathrm{NO}_{2}[\mathrm{M}+\mathrm{H}]^{+}:$507.9271, found: 507.8814 .

N-(3,5-Diiodo-4-methoxyphenethyl)-4-methylbenzamide (6)

Yield 45\% (48.9 mg, $0.09 \mathrm{mmol}$ ); white solid; ${ }^{1} \mathrm{H}$ NMR $\left(600 \mathrm{MHz}, \mathrm{DMSO}-d_{6}\right) \delta 8.43(\mathrm{t}, J 5.5 \mathrm{~Hz}, 1 \mathrm{H}, \mathrm{NH}), 7.69$ (d, J 6.4 Hz, 4H, H-9, H-2), 7.25 (d, J 8.0 Hz, 2H, H-10), $3.71\left(\mathrm{~s}, 3 \mathrm{H}, \mathrm{OCH}_{3}\right), 3.42(\mathrm{q}, J 6.7 \mathrm{~Hz}, 2 \mathrm{H}, \mathrm{H}-6), 2.75$ (t, J 7.0 Hz, 2H, H-5), 2.34 (s, 3H, $\left.\mathrm{CH}_{3}\right) ;{ }^{13} \mathrm{C} \mathrm{NMR}(151 \mathrm{MHz}$,
DMSO- $\left.d_{6}\right) \delta 166.25$ (C-7), 156.68 (C-4), 140.93 (C-11), 140.12 (C-2), 139.80 (C-1), 131.81 (C-8), 128.78 (C-10), 127.13 (C-9), 91.14 (C-3), $60.72\left(\mathrm{OCH}_{3}\right), 40.36$ (C-6), 32.97 (C-5), $20.95\left(\mathrm{CH}_{3}\right)$; ESI-Qtof-HRMS m/z, calcd. for $\mathrm{C}_{17} \mathrm{H}_{17} \mathrm{I}_{2} \mathrm{NO}_{2}[\mathrm{M}+\mathrm{H}]^{+}:$520.9349, found: 521.8941 .

$N$-(3,5-Diiodo-4-methoxyphenethyl)-4-methoxybenzamide (7)

Yield 45\% (50 mg, $0.09 \mathrm{mmol}$ ); white solid; ${ }^{1} \mathrm{H}$ NMR $\left(600 \mathrm{MHz}, \mathrm{DMSO}-d_{6}\right) \delta 8.37(\mathrm{t}, J 5.5 \mathrm{~Hz}, 1 \mathrm{H}, \mathrm{NH}), 7.77$ (d, J 8.7 Hz, 2H, H-9), 7.69 (s, 2H, H-2), 6.98 (d, J 8.7 Hz, $2 \mathrm{H}, \mathrm{H}-10), 3.80$ (s, 3H, $\mathrm{OCH}_{3}$ ), 3.71 (s, 3H, $\mathrm{OCH}_{3}$ ), 3.41 (q, $J 6.7 \mathrm{~Hz}, 2 \mathrm{H}, \mathrm{H}-6), 2.74$ (t, J 7.0 Hz, 2H, H-5); ${ }^{13} \mathrm{C} \mathrm{NMR}$ $\left(151 \mathrm{MHz}, \mathrm{DMSO}-d_{6}\right) \delta 166.80(\mathrm{C}-7), 161.46$ (C-11), 156.66 (C-4), 140.14 (C-1), 139.77 (C-2), 128.91 (C-9), 126.77 (C-8), 113.44 (C-10), $91.14(\mathrm{C}-3), 60.20\left(\mathrm{OCH}_{3}\right)$, $55.32\left(\mathrm{OCH}_{3}\right), 40.36$ (C-6), 33.03 (C-5); ESI-Qtof-HRMS $m / z$, calcd. for $\mathrm{C}_{17} \mathrm{H}_{18} \mathrm{I}_{2} \mathrm{NO}_{3}[\mathrm{M}+\mathrm{H}]^{+}:$537.9376, found: 537.8847 .

$\mathrm{N}$-(3,5-Diiodo-4-methoxyphenethyl)-4-nitrobenzamide (8)

Yield 45\% (55.3 mg, $0.10 \mathrm{mmol}$ ); white solid; ${ }^{1} \mathrm{H}$ NMR $\left(600 \mathrm{MHz}, \mathrm{DMSO}-d_{6}\right) \delta 8.85(\mathrm{t}, J 5.5 \mathrm{~Hz}, 1 \mathrm{H}, \mathrm{NH}), 8.31$ (d, J 8.7 Hz, 2H, H-10), 8.01 (d, J 8.7 Hz, 2H, H-9), 7.70 (s, 2H, H-2), 3.71 (s, 3H, $\mathrm{OCH}_{3}$ ), 3.47 (q, J $6.7 \mathrm{~Hz}, 2 \mathrm{H}$, H-6), 2.77 (t, J 7.0 Hz, 2H, H-5); ${ }^{13} \mathrm{C}$ NMR (151 MHz, DMSO- $\left.d_{6}\right) \delta 164.67$ (C-7), 156.74 (C-4), 148.95 (C-11), 140.14 (C-8), 139.79 (C-2), 128.61 (C-9), 123.52 (C-10), 91.17 (C-3), $60.21\left(\mathrm{OCH}_{3}\right), 40.56(\mathrm{C}-6), 32.75(\mathrm{C}-5)$; ESI-Qtof-HRMS $m / z$, calcd. for $\mathrm{C}_{16} \mathrm{H}_{15} \mathrm{I}_{2} \mathrm{~N}_{2} \mathrm{O}_{4}[\mathrm{M}+\mathrm{H}]^{+}$: 552.9121, found: 552.9148 .

\section{In vitro cytotoxicity}

Cytotoxicity of the compounds was evaluated on human U-937 macrophages (ATCC CRL-1593.2) in the exponential growth phase and adjusted at $1 \times 10^{5}$ cells $\mathrm{mL}^{-1}$ in RPMI-1640 enriched with $10 \%$ fetal bovine serum (FBS). $100 \mathrm{~mL}$ of cells were dispensed in each well of a 96-well microplate and $100 \mathrm{~mL}$ of $200,50,12.5$ or $3.125 \mu \mathrm{gL}^{-1}$ concentration of each compound were added. Cells exposed to compounds or standard drugs were incubated for $72 \mathrm{~h}$ at $37^{\circ} \mathrm{C}$ and $5 \%$ of $\mathrm{CO}_{2}$. Cytotoxic activity of each compound was determined according to the effect on the cell viability by the 3-(4,5-dimethylthiazol-2-yl)-2,5-diphenyltetrazolium bromide (MTT) micro enzymatic method in which MTT is reduced to a purple product named formazan by mitochondrial enzyme succinate dehydrogenase. Thus, $10 \mu \mathrm{L}$ well ${ }^{-1}$ were added to each well, and plates were incubated at $37{ }^{\circ} \mathrm{C}, 5 \% \mathrm{CO}_{2}$ for $3 \mathrm{~h}$. The reaction was stopped by adding $100 \mu \mathrm{L}$ well ${ }^{-1}$ of isopropanol with 50 and 
$10 \%$ of sodium dodecyl sulfate (SDS). The concentration of formazan was spectrophotometrically determined at $570 \mathrm{~nm}$ (Varioskan, Thermo) and the intensity of the color (absorbance) was registered as optical densities (O.D.). Cells exposed to control drugs chloroquine, amphotericin $\mathrm{B}$, benznidazole, and doxorubicin were used as positive control for toxicity, while cell incubated in RPMI-1640 medium alone were used as negative control. Non-specific absorbance was corrected by subtracting absorbance (O.D.) of the blank. Determinations were done by triplicate in at least two independent experiments. ${ }^{11}$

\section{Hemolytic activity}

The ability to induce hemolysis was specifically evaluated to compounds which showed antiplasmodial activity following the method of cytotoxicity by spectrophotometry on 96-well plates. Briefly, $500 \mu \mathrm{L}$ of human red blood cells (huRBC), adjusted to $5 \%$ hematocrit in RPMI-1640 medium, were placed into each well of a 24-well plate and subsequently exposed to $200 \mu \mathrm{g} \mathrm{mL}-1$ of compounds 1-8. Detection of free hemoglobin, after $48 \mathrm{~h}$ of incubation at $37{ }^{\circ} \mathrm{C}$, was the evidence that the compound induced hemolysis. The concentration of free hemoglobin was spectrophotometrically read at $542 \mathrm{~nm}$ (Varioskan, Thermo) and O.D. were registered. Non-specific absorbance was corrected by subtracting absorbance of the blank. Determinations were done by triplicate in at least two independent experiments. ${ }^{12}$

\section{In vitro anti-leishmanial activity}

Anti-leishmanial activity of iodotyramides was determined according to the ability of the compound to reduce infection by L. panamensis parasites. ${ }^{13}$ Briefly, U-937 human cells at a density of $3 \times 10^{5}$ cells $\mathrm{mL}^{-1}$ in RPMI 1640 and $0.1 \mu \mathrm{g} \mathrm{mL} \mathrm{m}^{-1}$ of phorbol-12-myristate-13-acetate (PMA) were dispensed on 24-wells microplate and then infected with stationary phase growing $L$. panamensis promastigotes (MHOM/CO/87/UA140-E-GFP strain) in a 15:1 parasites per cell ratio. Plates were incubated at $34{ }^{\circ} \mathrm{C}$ and $5 \% \mathrm{CO}_{2}$ for $3 \mathrm{~h}$ and then cells were washed twice with phosphate buffer solution (PBS) to eliminate not internalized parasites. Fresh RPMI-1640 was added to each well (1 mL) and plates were incubated again to complete infection. After $24 \mathrm{~h}$ of infection, the RPMI-1640 medium was replaced by fresh culture medium containing each compound at four serial dilutions $\left(50,12.5,3.125\right.$ and $\left.0.78 \mu \mathrm{g} \mathrm{mL}^{-1}\right)$ and plates were incubated at $37^{\circ} \mathrm{C}$ and $5 \% \mathrm{CO}_{2}$ for $72 \mathrm{~h}$; then, cells were removed from the bottom plate with a $100 \mu \mathrm{L}$ trypsin/ethylenediaminetetracetic acid (EDTA) solution. The cells were centrifuged at $1100 \mathrm{rpm}$ during $10 \mathrm{~min}$ at $4{ }^{\circ} \mathrm{C}$, the supernatant was discarded and cells were washed with $1 \mathrm{~mL}$ of cold PBS and centrifuged at $1100 \mathrm{rpm}$ for $10 \mathrm{~min}$ at $4{ }^{\circ} \mathrm{C}$. Cells were washed two times employing PBS, as previously, and after the last wash, the supernatant was discarded and cells were suspended in $500 \mu \mathrm{L}$ of PBS. Cells were analyzed employing a flow cytometer (Cytomics FC 500MPL) reading at $488 \mathrm{~nm}$ (exciting) and $525 \mathrm{~nm}$ (emitting) over an argon laser and counting 10,000 events. Infected cells were determined according to the events for green fluorescence (parasites). Infected cells exposed to amphotericin B (standard antileishmanial drug) were used as control for anti-leishmanial activity (positive control), while infected cells incubated in absence of any compound or drug were used as control for infection (negative control). Nonspecific fluorescence was corrected by subtracting fluorescence of unstained cells. All determinations were performed by triplicate in at least two independent experiments. ${ }^{11,13}$

\section{In vitro anti-trypanosomal activity}

To test the effectiveness of compounds, 25,000 U-937 human macrophages/100 $\mu \mathrm{L}$ RPMI-1640 enriched with $10 \%$ FBS and 10 ng PMA were placed in each well of 96-wells cell culture plate. Cells were then infected with epimastigotes ( $24 \mathrm{~h}$ of growing) of $T$. cruzi Tulahuen strain transfected with $\beta$-gal gene (donated by Dr F. S. Buckner, University of Washington) in 5:1, parasites:cell ratio. After infection, $100 \mu \mathrm{L}$ of each compound at 50, 12.5, 3.125 or $0.78 \mu \mathrm{g} \mathrm{mL}^{-1}$ were added to each well and plates were incubated during $72 \mathrm{~h}$ at $37{ }^{\circ} \mathrm{C}, 5 \% \mathrm{CO}_{2}$. Finally, the effect of each compound and each concentration on the viability of intracellular parasites was determined by measuring $\beta$-gal activity by colorimetric method after adding $100 \mu \mathrm{M}$ CPRG and $0.1 \%$ nonidet P-40. After $3 \mathrm{~h}$ of incubation at room temperature plates were read at $570 \mathrm{~nm}$ in a spectrophotometer (Varioskan, Thermo) and absorbance was recorded as O.D. Anti-trypanosomal activity of benznidazole was used as positive control, while RPMI-1640 medium was used as negative control. Non-specific absorbance was corrected by subtracting O.D. of the blank. Determinations were done by triplicate in at least two independent experiments. ${ }^{14}$

\section{In vitro anti-plasmodial activity}

Asynchronized $P$. falciparum 3D7 strain cultures were adjusted to $0.5 \%$ parasitemia and $1 \%$ hematocrit in RPMI medium enriched with $3 \%$ lipid-rich bovine serum albumin-Albumax II. Then, $100 \mu \mathrm{L}$ of parasite suspension 
was dispensed into each well of 96-wells cell culture plate and subsequently exposed to $100 \mu \mathrm{L}$ of each compound at $100,25,6.25$ or $1.56 \mu \mathrm{g} \mathrm{mL} \mathrm{m}^{-1}$. Plates were incubated for $48 \mathrm{~h}$ at $37{ }^{\circ} \mathrm{C}$ in $\mathrm{N}_{2}(90 \%), \mathrm{CO}_{2}(5 \%)$ and $\mathrm{O}_{2}(5 \%)$ atmosphere. After incubation, parasites were harvested and subjected to three 20 min freeze-thaw cycles. Meanwhile, $100 \mu \mathrm{L}$ of Malstat reagent $(400 \mu \mathrm{L}$ Triton X-100 in $80 \mathrm{~mL}$ deionized water, $4 \mathrm{~g} \mathrm{~L}^{-1}$ lactate, $1.32 \mathrm{~g}$ Tris buffer and $0.022 \mathrm{~g}$ acetylpyridine adenine dinucleotide in $200 \mathrm{~mL}$ deionized water; $\mathrm{pH} 9.0$ ) and $25 \mathrm{~mL}$ of NBT/PES solution (0.16 g nitroblue tetrazolium salt and $0.08 \mathrm{~g}$ phenazine ethosulphate in $100 \mathrm{~mL}$ deionized water) were added to each well of a second 96-well plate. After freeze-thaw cycles, culture in each of the wells of the first plate was resuspended by pipetting and $15 \mu \mathrm{L}$ of each well was taken and added to the corresponding well of the second plate (containing Malstat and NBT/PES reagents). After an hour of incubation in the dark, color development of the LDH (lactate dehydrogenase) reaction was read in a spectrofluorometer (Varioskan, Thermo) at $650 \mathrm{~nm}$. The intensity of color in each experimental condition was registered as fluorescent units (F.U.). Non-specific fluorescence was corrected by subtracting F.U. of the blank. Determinations were done by triplicate in at least two independent experiments. Chloroquine (CQ) was used as positive control and culture medium was used as negative control. ${ }^{15}$

\section{Statistical analysis}

Cytotoxicity of iodotyramides was tested in comparison to doxorubicin, amphotericin B, benznidazole, chloroquine and RPMI-1640 culture medium. The results were expressed as $\mathrm{LC}_{50}$ that corresponds to the concentration necessary to eliminate $50 \%$ of cells and calculated by Probit analysis. Cell growth inhibition was calculated by equation 1 :

$\%$ Cell growth inhibition $=100-\left[\frac{\text { O.D. } \text { exposed cells }}{\text { O.D. control cells }} \times 100\right]$

The degree of toxicity was graded according to the $\mathrm{LC}_{50}$ value using the following scale: high cytotoxicity: $\mathrm{LC}_{50}<100 \mu \mathrm{g} \mathrm{mL} \mathrm{mL}^{-1}$; moderate cytotoxicity: $\mathrm{LC}_{50} 100-200 \mu \mathrm{g} \mathrm{mL}^{-1}$ range and potentially non-cytotoxicity: $\mathrm{LC}_{50}>200 \mu \mathrm{g} \mathrm{mL} \mathrm{m}^{-1}$.

Anti-leishmanial activity was determined according to the reduction of the median fluorescence intensity (MFI) of infected cells obtained for each experimental condition by the cytometer. The parasite amount was calculated by equation 2, where the MFI in infected cells in the control well corresponds to $100 \%$ of infection.

$\%$ Inhibition of infection $=100-\left[\frac{\text { MIF compounds exposed infected cells }}{\text { MIF culture medium infected cells }} \times 100\right]$
Anti-plasmodial activity of each evaluated compound was evidenced by the reduction of growing parasites calculated according to equation 3 :

$\%$ Parasite growing inhibition $=100-\left[\frac{(\text { U.F. compounds exposed parasites })}{\text { (U.F. culture medium parasites) }} \times 100\right]$

Anti-trypanosomal activity was calculated by reduction of infection (viable parasites) in each tested concentration. For this, reduction of the number of parasites was calculated with equation 4 :

$\%$ Infection inhibition $=100-\left[\frac{\text { O.D compounds exposed infected cells }}{\text { O.D culture medium infected cells }} \times 100\right]$

Percentages of reduction of parasites data were used to calculate the $\mathrm{EC}_{50}$ using the linear regression model Probit. ${ }^{16}$

Anti-leishmanial, anti-plasmodial and antitrypanosomal activities were graded as high, moderate or low according to the $\mathrm{EC}_{50}$ values, as follow: high activity when the $\mathrm{EC}_{50}<25 \mu \mathrm{g} \mathrm{mL}^{-1}$; moderate activity $\mathrm{EC}_{50}$ ranging between $25-50 \mu \mathrm{g} \mathrm{mL}^{-1}$ and low activity when the $\mathrm{EC}_{50}>50 \mu \mathrm{g} \mathrm{mL}^{-1}$. SI was calculated by dividing the cytotoxic activity and the anti-leishmanial, anti-trypanosomal and antiplasmodial activity using the following formula: $\mathrm{SI}=\mathrm{LC}_{50} / \mathrm{EC}_{50}$.

\section{Supplementary Information}

Supplementary data $\left({ }^{1} \mathrm{H},{ }^{13} \mathrm{C}\right.$ and $2 \mathrm{D}$ NMR spectra, and ESI-Qtof-HRMS) are available free of charge at http://jbcs.sbq.org.br as a PDF file.

\section{Acknowledgments}

The authors would like to thank the Departamento Administrativo de Ciencia, Tecnología e Innovación de Colombia-Colciencias (grant CT-695-2014) and to Comité para el Desarrollo de la Investigación, Universidad de Antioquia (Proyect CODI CIQF-176) for their financial support.

\section{References}

1. Murphy, C. D.; J. Appl. Microbiol. 2003, 94, 539.

2. Solano, G.; Motti, C. A.; Jaspars, M.; Tetrahedron 2009, 65, 7482.

3. Sesin, T. F.; Ireland, C. M.; Tetrahedron Lett. 1984, 25, 403.

4. Diop, M.; Samb, A.; Costantino, V.; Fattorusso, E.; Mangoni, A.; J. Nat. Prod. 1996, 59, 271.

5. Kigoshi, H.; Kanematsu, K.; Yokota, K.; Uemura, D.; Tetrahedron 2000, 56, 9063. 
6. Younai, A.; Chin, G. F.; Shaw, J. T.; J. Org. Chem. 2010, 75, 8333.

7. Hackenmueller, S. A.; Scanlan, T. S.; Synth. Commun. 2013, 43, 1439.

8. Vyas, G. N.; Shah, N. M.; Org. Synth. 1951, 31, 90.

9. Coleman, C. M.; O'Shea, D. F.; J. Am. Chem. Soc. 2003, 125, 4054.

10. Valeur, E.; Bradley, M.; Chem. Soc. Rev. 2009, 38, 606.

11. Taylor, V. M.; Cedeño, D. L.; Muñoz, D. L.; Jones, M. A.; Lash, T. D.; Young, A. M.; Constantino, M. H.; Esposito, N.; Vélez, I. D.; Robledo, S. M.; Antimicrob. Agents Chemother. 2011, 55, 4755.

12. Conceição, K.; Konno, K.; Richardson, M.; Antoniazzi, M. M.; Jared, C.; Daffre, S.; Camargo, A. C. M.; Pimenta, D. C.; Peptides 2006, 27, 3092.
13. Pulido, S. A.; Muñoz, D. L.; Restrepo, A. M.; Mesa, C. V.; Alzate, J. F.; Vélez, I. D.; Robledo, S. M.; Acta Trop. 2012, 122, 36.

14. Valencia, L.; Muñoz, D. L.; Robledo, S. M.; Echeverri, F.; Biomédica 2011, 31, 552.

15. Nkhoma, S.; Molyneux, M.; Ward, S.; Am. J. Trop. Med. Hyg. 2007, 76, 1107.

16. Finney, D. J.; Statistical Method in Biological Assay; Griffin: London, 1978, p. 508-510.

Submitted: June 15, 2018

Published online: August 20, 2018 